\title{
Creative Techniques in the Framework of Market and Evolution ${ }^{1}$
}

\author{
Istvan Magyari-Beck \\ Professor Emeritus, Corvinus University of Budapest \\ E-mail: istvan.magyari.beck@uni-corvinus.com
}

\author{
Mahshid Moradi \\ PhD Student, Corvinus University of Budapest \\ E-mail:
}

This paper tries to reframe the man-machine problem, which has frequently changed throughout history. Originally, a machine was a helper of man, but later became its competitor and substitute. As a consequence of this, man has been pushed out of production and possibly, out of life itself. For today, nearly all the man's functions - except for consumption and creativity - can be furnished by machines. Creativity should have a special place because it is the last "shelter" of man in the conflict with machine. Almost every other faculty of man has more or less been simulated by technology. There are some key questions to be answered: Whom do the creative techniques serve? Is the target group the men or machines?

Keywords: creativity, technical civilization, human genome, creative techniques, market as a battlefield

\section{JEL-codes: L26}

\section{Man and Machine, Facts and Reasons}

One of the main problems in our historical period is the relationship between the power of man and the power of technology. These two rival powers (behind which one can find rival groups of people) are similar to each other in many respects. Nevertheless, for centuries man was the winner. However, technology has gained the first position by now and it becomes more and more powerful. As far as man is concerned, he seems to be the loser. This state of affairs can easily be grasped in the real life. At first, machines were just useful things. They could help people, however, only to a minimal degree. As the progress went on, this role of technology has been growing. Machines - instead of helping people - have taken over a growing number of tasks from the labor force. In the end, technology, which was originally a precious aid, became a curse. Workers were turned into unnecessary creatures and became first underutilized, then unemployed. Machine work has increased, and the role of the human population, well equipped by knowledge and skills, has shrunk. This led to a decrease of the

\footnotetext{
${ }^{1}$ Assistance provided by Irina Surkova in planning and distributing the questionnaires in Latvia of the survey presented was greatly appreciated.
} 
population of working people - moreover a large part of people at large - created by the overpopulation of machines.

\section{More Details and Aspects}

Now, let us see the anthropological development from the point of view of creativity. It is an old commonplace that man was the weakest animal. Thus, people had to be creative in order to survive. The whole technical progress was the manifestation of human creativity and had altogether six comprehensive phases: (1) the invention of the human body as the first tool, (2) the invention of simple machines, (3) the invention of power production, (4) the invention of complex movable machinery, (5) the invention of artificial intelligence, and last but not least, (6) the invention of artificial creativity.

Today, the sixth step is at its very beginning. Before continuing the discussion of this matter, the first phase needs comments. Our body had to be invented (or reinvented?) because it had alienated from us due to the human genome, being fatally injured at the beginning of anthropogenesis (Watson - Berry 2003). Speaking philosophically, the birth of the body as something semi-independent from man took place relatively later.

Religion and philosophy inherited and preserved a hierarchical relationship between the highclass mind and the 'dirty' body, both theoretically and in practice, for a considerable time. On the other hand, exactly this self image of man helped him to create high level quality cultures and civilizations in prehistory. We mean by culture the men's artificial inner program and a psychological order and harmony based on it, whereas civilization is considered as a system of outer material and spiritual tools. Civilizations blossom coherently. Coherence, supplementation and a certain harmony are the way of how civilizations have always been progressing (Magyari-Beck 1976). There are a lot of facts supporting this view. Take just as examples the English industrial revolution, the development of the war industry in the First and Second World Wars and the nuclear age. The development of offensive weapons goes hand in hand with that of the defensive weapons. This is why the future can be predicted logically to a certain degree.

It follows from the foregoing that the six phases of technical development also have their predictable logic. It is not difficult to see, that those six phases make us anticipate a dark future. The first phase of the invention of the body was mainly the opening step towards man's picture about himself as having a problem nature (prehistoric age). The second phase simulates mainly the forms of working motions by the labour force. This was before and during the technical revolution of the middle ages in Europe (Endrei 1978). The third phase mainly made use of generalized human energy, based on internal combustion (the English industrial revolution during the $18^{\text {th }}$ century). The fourth phase models mainly the complex integrated human motions in the production of goods. The fifth phase imitates mainly human intelligence (scientific and technological revolution in the $20^{\text {th }}$ century). Finally, in the sixth phase, we are mainly trying to copy the laws of human creativity.

Historical periods are not the mutually excluding kinds, they are rather types, overlapping in time, which guarantee historical continuity. Thus, the whole technical development is a grand 
experiment which brings into existence a machine-like new man: perhaps the superman, who originally was a dream and subsequently, a goal in western civilization in the $19^{\text {th }}$ century.

The newborn giant has not yet reached its maturity. It is still in an early period of childhood. However, its abilities are not only approximating the human faculties, but in some respects have outgrown them as well. The giant can regulate its body (automation); can perform usable work (robots); can be extremely robust (power); can calculate logically (artificial intelligence); and soon will be able to innovate (artificial creativity). What makes the matter breathtakingly dangerous is the fact according to which the technical development of our evolutional enemy has a much better position than the improvement of people via education. Robotics is supported financially much better than the educational system. As if mankind had given up (or is giving up) its leading position on Earth.

\section{An Indispensable Remark}

The man, whose ideas the citation below speaks of, is Adam Smith, a great British economist of the $18^{\text {th }}$ century. A section below is a long citation from the work of Professor Dmitry Reut (2013: 2). It shows to what extent a false direction could deteriorate the thinking of a whole science and, guided by it, even the practice for a considerable time.

\footnotetext{
We suppose that the broadening of the discussion context of economic problems is not only desirable but necessary. One of the reasons is the fact that the very existence of the most powerful economy - the economy of the Western World (in the broad sense, including the USA) is under threat. In this connection we take notice not of economic crisis but of a demography problem. This decision is based on the antique interpretation of economy (Oikonomike), including the whole world of housekeeping broadened to the limits of the state. So it embraced the discipline of population reproduction. The last adherents of this interpretation were the Physiocrats (Francois Quesnay, Anne-Robert-Jacques Turgot, Pierre Samuel du Pont de Nemours, etc.). Subsequently Adam Smith narrowed sharply the economic branch of science and it turned out to be isolated from the discipline of population reproduction.
}

Therefore, Smith himself - originally a university professor and rector - was the root of economics' ignorance in culture, education, public health, art, humanities and social sciences, etc. Great thinkers many times submit great nonsense. History clearly shows that the greater a thinker is, the greater mistakes they can from time to time produce.

\section{Importance, Directions and Organizations of Creativity}

We are not Luddites. We like techniques and technologists. However, everything should have their reasonable limits. Epistemologically reasonable limits and essence of entities are the same things. The essence of technical and technological tools is in a kind of symbiotic coexistence with man. The same message is carried by the desirable limitations of technical civilization. It follows from this sameness that to transcend the limits of an entity equals with its destruction. The technical civilization which is at war with humankind instead of maintaining a symbiotic relationship can soon collapse. Quite a few biologists spoke of this giant as a living system, reducing life to self-reproduction (Wilson 2006; Dawkins 2007). This means that the problem is already known and the battlefield is the market. For the time being, 
creativity remains the main attribution of man. This allows a prediction that the battle between the giant and mankind will occur in the domain of creativity. Are we people ready for this combat? Can we re-establish the original symbiotic relationships between the technical civilization and the culture of man via the radical restriction of the triumphant machine? That's question number one for now.

Like all the topics, our "armed forces", namely creativity, are studied and trained in a number of ways. Admittedly, a part of studies attempts to discover the essence of creativity, many times forgetting about its application. Whereas the other part tries to invent the phenomena of creativity, many times forgetting about the basic investigations. In all likelihood, the number of discoverers is much smaller than the number of inventors in this domain.

Unfortunately, there is no widespread statistical survey of the huge international network of organizational units. Neither are we familiar with any classification or typology of these units. Our limited knowledge allows us to have only examples. Such examples of institutions of basic investigations into creativity are: the Riga Scientific Institute of Creativity, organized and guided by Professor Rita Bebre. One of its subdivisions is the International Centre for Science of Creatology. This institute published a large number of excellent scientific papers. Some outstanding Latvian works were published in international journals (Surkova 2012). Basic researches are run in the University of Cassino, in the Centre of Philosophy at the Corvinus University of Budapest, in Free University of Bozen-Bolzano (Pedroni - Volonte, 2008). The members of the miniature sample in this paper were all European organizations and mostly follow a European tradition of basic studies.

However, the mainstream is flourishing in the United States of America and practices invention of creative techniques. The huge number of the mainstream centres (eg. the Buffalo Creative Problem Solving Group organized by Scott G. Isaksen, the International Center for Studies in Creativity, the Torrance Center, the Center for Creative Education, etc.) invent and improve creative techniques. The standard skeleton of inventions is to design a method and improve it experimentally, which obligatorily needs control groups as well. As a matter of fact, any experiment is unthinkable without theoretical underpinnings. We can only guess that a pioneering centre for creatology the Iran Research Center for Creatology, established by Sayed Mahdi Golestan Hashemi, is able to combine both theoretical and practical approaches. But this centre is still isolated from the profession, perhaps because of political reasons. If it is true, that will be a great shame, especially on the part of our Euro-Atlantic culture. Much has been devoted to the importance of scholars in mitigating international discord (Allison Keynan 1998). This movement was started in Europe by Madame Curie just after the end of the First World War.

\section{Some Suppositions: What to Know and How to Know?}

Pursuant to the train of thought of this article, we are interested in the market position of instructions coming from the creativity studies. We are starting the search with creative techniques. Now, if the creative techniques are successful on the market, they fulfill the needs of people engaged in creative work. If creative techniques are not successful, they cannot 
fulfill the needs of creative work. The fact is that creative techniques exist. Why? So far, we only have two possible explanations: (1) creative techniques exist as they fulfill the needs of creators. (2) creative techniques exist because the need for it comes from other sources. What can be these sources? A public enchanted by an enchanter's mental spectacle? High schools' or universities' students, who prefer mental delicacies? Managers who force the use of creative techniques? Constructors of machines, who are hungry for victory over humanity? In order to clarify at least a part of these questions, we have designed an empirical study. As we were unable to obtain the necessary financial support from any sources, this survey is rather a work in progress, enough for the problem framing.

\section{Research Design}

Survey questionnaires were designed and distributed to Hungarian, Latvian and Iranian full professors, associate professors, assistant professors and $\mathrm{PhD}$ students whose work regularly includes problem solving and idea generation. The vast majority of the small sample were Hungarians. The participants were asked to indicate their sex, age, position at their workplace and the number of creative tasks - one, two, three - they had elaborated on before. We were also interested in their comments attached to these questions. The further questions were devoted to issues on the demand, usability, usefulness, rank order, acceptance and the popularity of creative techniques. We also gathered data on stability, sovereignty, competence, the independence of, familiarity or ignorance with creative techniques by participants. Some habits of using creative techniques were also clarified by the survey. The first question of the questionnaire was about the proportion between the potential and actual participants indicating the interest towards the domain of creative techniques among the creative problem solvers. While potential participants were those to whom we distributed our questionnaire, the actual participants were those who answered our questions. The elementary indicators and the actual questionnaire are presented in the Appendix.

\section{Description of Results}

Two hundred questionnaires were distributed and 74 returned. The overall return rate is $37 \%$ (indicators 0 and 1 in Table 1). Among them, 32 women and 42 men answered the questionnaire (indicators 2 to 3). In respect of the age, respondents were divided into 5 categories: aged 20-30, 31-40, 41-50, 51-60 and over 60 years and therefore respectively 33, $17,6,10$ and 8 persons were in each age category (indicators 4 to 8 ). Eleven full professors, 5 associate professors, 9 assistant professors and $49 \mathrm{PhD}$ students responded (indicators 9 to 12).

As for the degree of mental activity, 19 persons have said that they have solved one creative problem at their workplace. Two problems were solved by 14 persons, and three by 18 persons. 23 persons did not answer the questions (indicators 13 to 16). In respect of demand for Creative Techniques, 41 persons were identified who have used creative techniques at their workplace in the past, while 33 persons are currently using these techniques (indicators 17 to 18 ). We found 40 persons who have not used these techniques at the workplace in the past, and 34 persons who do not use them now (indicators 19 to 20). 
Looking for the people of different kinds of stability we found the following results: 60 people who (a) used creative techniques at the workplace and still use them, (b) plus who have never used any creative techniques and have preserved this habit (indicator 21). We also found 14 unstable people who (a) have used creative techniques in the past, but have stopped using them, or (b) who have never used creative techniques in the past, but use them currently (indicator 22).

We are interested in the degree of positive and negative stability, as well. Thus, 33 people from our sample used creative techniques in the past and use them now (positive stability). On the other hand, 27 persons did not use creative techniques in the past and continue not to use them today (negative stability) (indicators 23 to 24). We have 7 "drop outs" - originally a term coined at the Center for Studies in Creativity at New York State University College at Buffalo - in the sample, who used creative techniques in the past, however, they have turned them off for now, and also 7 "newcomers" not being eager students and practitioners of creative techniques, but today they are happy to use them (indicators 25 and 26).

As for the popularity of creative techniques, the rank order of these techniques was as follows. 52.7 percent of total participants in our sample preferred the brainstorming technique, 13 percent preferred the Six Thinking Hat techniques, 12.2 percent preferred Synectics techniques, 10.8 percent preferred Heuristics and only 8.1 percent preferred TRIZ. An interesting fact is that 12.2 percent had their own individual techniques and some others mentioned the CPS and Heuristics technique (indicator 27).

Our participants were also asked about (1) the degree of their subjective attractions to creative techniques and about (2) the outer forces in the workplace which either stimulated them to use these techniques or prevented them from using the techniques in question. 37 respondents proved to be sovereign in either using or not using creative techniques at their workplace. However, 12 respondents had been forced either to use or not to use these techniques. 18 respondents were absolutely ignorant of these techniques (indicators 28 to 30 ).

Table 1. Results of the survey

\begin{tabular}{|l|l|c|c|c|}
\hline$\#$ & \multicolumn{1}{|c|}{ Indicators } & Formulas & $\begin{array}{c}\text { number of } \\
\text { respondents }\end{array}$ & $\begin{array}{c}\text { Percent } \\
\text { of total }\end{array}$ \\
\hline 0 & Number of Questionnaire distributed & & 200 & \\
\hline 1 & Respondents & & 74 & $37 \%$ \\
\hline 2 & Women/whole sample & & 32 & $44.44 \%$ \\
\hline 3 & Men/whole sample & & 42 & $56.75 \%$ \\
\hline 4 & Age $20-30$ & & 33 & $44.59 \%$ \\
\hline 5 & Age $31-40$ & & 17 & $22.67 \%$ \\
\hline 6 & Age $41-50$ & & 6 & $8.10 \%$ \\
\hline 7 & Age $51-60$ & & 10 & $13.51 \%$ \\
\hline
\end{tabular}




\begin{tabular}{|c|c|c|c|c|}
\hline 8 & Age $61+$ & & 8 & $10.81 \%$ \\
\hline 9 & Full professor & & 11 & $14.86 \%$ \\
\hline 10 & Associate professor & & 5 & $6.75 \%$ \\
\hline 11 & Assistant professor & & 9 & $12.16 \%$ \\
\hline 12 & PhD student & & 49 & $66.20 \%$ \\
\hline 13 & Degree of mental activity-4a & one problem solved & 19 & $25.67 \%$ \\
\hline 14 & Degree of mental activity- $4 b$ & two problem solved & 14 & $18.91 \%$ \\
\hline 15 & Degree of mental activity-4c & three problem solved & 18 & $24.32 \%$ \\
\hline 16 & Degree of mental activity-4d & no comment on this question & 23 & $31.08 \%$ \\
\hline 17 & Previous demand for $\mathrm{CT}$ & has used CTs in the past at work & 41 & $55.40 \%$ \\
\hline 18 & Current demand for CT & is currently using CT at work & 33 & $44.59 \%$ \\
\hline 19 & No previous demand for CT & $\begin{array}{l}\text { has not used CTs in the past at } \\
\text { work }\end{array}$ & 40 & $54.05 \%$ \\
\hline 20 & No current demand for CT & does not use CTs now at work & 34 & $45.94 \%$ \\
\hline 21 & Degree of stability & $\begin{array}{l}\text { has used creative techniques at } \\
\text { the workplace and still uses them } \\
\text { + has never used any creative } \\
\text { techniques and has preserved this } \\
\text { habit }\end{array}$ & 60 & $81.08 \%$ \\
\hline 22 & Degree of instability & $\begin{array}{l}\text { has used creative techniques in } \\
\text { the past, but has stopped using } \\
\text { them + has never used creative } \\
\text { techniques in the past, but uses } \\
\text { them currently }\end{array}$ & 14 & $18.91 \%$ \\
\hline 23 & Degree of positive stability & $\begin{array}{l}\text { used CT in the past and uses it } \\
\text { today }\end{array}$ & 33 & $44.59 \%$ \\
\hline 24 & Degree of negative stability & $\begin{array}{l}\text { did not use CT in the past and } \\
\text { does not use it today }\end{array}$ & 27 & $36.48 \%$ \\
\hline 25 & Degree of drop outs & $\begin{array}{l}\text { used CT in the past, but does not } \\
\text { use it anymore }\end{array}$ & 7 & $9.45 \%$ \\
\hline 26 & Degree of new comers & $\begin{array}{l}\text { did not use CT in the past but } \\
\text { uses it now }\end{array}$ & 7 & $9.45 \%$ \\
\hline 27 & The popularity of CTs & rank order of CTs used & 30 & $40.54 \%$ \\
\hline 28 & Degree of sovereignty at the workplace & $\begin{array}{l}\text { useful + not useful+ learned }+ \\
\text { disappointed }\end{array}$ & 37 & - \\
\hline 29 & Degree of existing force at the workplace & obliged + not obliged + forbidden & 12 & - \\
\hline 30 & Degree of being informed & ignorance concerning $\mathrm{CT}$ & 18 & - \\
\hline
\end{tabular}

\section{Discussion}


We begin the data processing with the transformation of raw indicators from integers into percentages. This step can be called a mathematical generalization. We are aware of the fact that the sample we presented in this paper is too small to arrive at valid generalizations. In all likelihood, the main contribution of this work in progress will be methodological.

We start the analyses of our data with interests towards the domain and field of creative techniques. The proportion between those to whom we sent questionnaires and those who answered them was 37 percent. At first glance the percentage of interest in creative techniques is considerable. However, if we compare this data to our lifelong observations, the result would seem the reverse. This can be supported by the fact according to which creative techniques are not popularized sufficiently either on the market or scientifically. Perhaps because creative techniques have up till now been rather inventions of resourceful minds of bright specialists in creativity, than the discoveries of diligent, hard-working and erudite, people in interdisciplinary field. Who knows?

In our opinion, a much better option of studying creative techniques would be the investigation into biographies of outstanding people and finding the methods they used in the process of their inventions and discoveries. This trend can be called "Intellectual Taylorism" as first we are looking for the best and the most successful creative techniques and then propose - or even require - the use of them by scholars and inventors. It is also possible to sum up "Original Taylorism" and "Intellectual Taylorism" and start working on the "Universal Taylorism" in the name of excellence. Incidentally, "Universal Taylorism" itself is a much larger concept than the two Taylorisms combined, because it contains all the best achievements in whatever topic. For example: in work, in diligence, in intelligence, in energy, in creativity, in erudition and so on, however, also in beauty, in relaxing, in making fun, in love, in sport, in enjoying holiday and so on. The Universal Taylorism has nothing to do with the German Übermensch or the American superman, as the first inherited, while the second learned his or her faculties.

It is a promising sign that the largest parts of the sample were the young, of ages between 21 and 30 (33 persons with 44.59\%) and $\mathrm{PhD}$ students (49 persons with 66.20\%). Young intellectuals will stay on the market of creative techniques for a considerable time. Moreover, they can and should study and apply high quality level creative techniques. This can happen if and only if the demand side of this market is completed with a large supply of high quality creative techniques. The science of Creatology has always put a great emphasis on basic research in creativity. We creativity scholars should at first study and make discoveries in real life creativity practice and only subsequently - and not before - construct better inventions.

As for the mental activity of our participants, the overall picture is sorrowful. Approximately one third of the participants -23 people or 31.08 percent - had no comments to question 16 . What could be the reason for this? We think it is the relentless monetization in the EuroAtlantic civilization. One cannot participate in any committee or meeting where the problem of finance would not be the chief topic. What has happened to this culture? The answer seems simple, namely: managerism. Originally, managers were the persons who ran the business established by an innovator and inventor. Now, however, a lot of them simply monitor the difference between the investment and return, strictly in terms of money. This can be made 
without special knowledge in the domain. The evident model is mutatis mutandis the commissar of early communism in the Soviet Union. This mentality can destroy the whole Euro-Atlantic culture.

Most of the questions refer to the use of the creative techniques by participants in the past and present. We did not ask our respondents about their intentions concerning the use of these techniques in the future. Admittedly, this is one of the weaknesses of this study. Well, 41 participants $(55.40 \%)$ used creative techniques at their workplace however, 33 persons $(44.59 \%)$ are still using them there. Here we are confronted by stability, which is possibly not significant. Similar results were given by the next two indicators. 40 participants $(54.05 \%)$ did not work with creative techniques and 34 (45.94\%) persons in our sample do not work with them now, either. These data were not interpreted by us, but they were made use of in more complex indicators, such as stability and instability of working skills. Here we found amazingly expressive data. 60 people $(81 \%)$ proved to be stable in their ways of using creative techniques both in the past and present. While only 14 people $(18.91 \%)$ were unstable from the same point of view. We regard these findings very important and guess that they are significant. Euro-Atlantic culture and civilization - or its leaders - either forgot all about the basic need of security or they create unsecure political, ecological, economic, military and cultural environment and circumstances intentionally. This regrettable game could be very dangerous. Recall the historical period during and after the First World War, when Central Europe and Western Russia were in an especially great chaos. The sad outcomes of this chaos were Fascism and Communism. We do not think it would be fruitful to return to those periods.

The last 8 indicators are not so interesting, except for the numbers of "drop outs" and "newcomers". These numbers are especially small, and confirmed the stability of attitudes concerning the mobility to and from the creative techniques. It is also worth mentioning that workplaces do not require the use of creative techniques (see the indicator 29). On the other hand, the large majority of members of university staffs are informed on the existence of creative techniques but they do not utilize them (see indicator 30). So we can arrive at the conclusion that these techniques are at the very beginning of their market career. And in all likelihood, this career will rather promote the construction of creative machines, than the fulfilment of the requirements of creative labour.

\section{Conclusions}

The proposals of the authors are as follows. It would be advisable to repeat this study many times, using improved theories and methods. Instead of inventing newer and newer creative techniques, investigators into creativity must at first study the methods of the highest quality researchers and inventors in the spirit of the basic science of Creatology. Without valid theories it is impossible to be successful in the practice. The science of creativity should not forget the last phase of CPS, namely the "Acceptance Finding". This can lead to a larger supply, demand and distribution of creative techniques. The creative techniques should serve mankind instead of serving industrial technology. So if we are successful, the power of the human mind will be lifted up to the level of our social, economic, political, technological, 
environmental, demographic and so on problems. Last but not least, do not forget the importance of market nature of creative techniques in the twenty first century.

\section{References}

Allison, L. C. C. - Keynan, A. (eds) (1998): Scientific Cooperation, State Conflict. The Roles of Scientists in Mitigating International Discord. New York: The New York Academy of Sciences.

Dawkins, R. (2007): The God Delusion. London: Black Swan Books.

Endrei, W. (1978): A középkor technikai forradalma [Technical Revolution of the Middle Ages]. Budapest: Magvető Kiadó.

Magyari-Beck, I. (1976): Kísérlet a tudományos alkotás produktumának interdiszciplináris meghatározására [An Attempt of Interdisciplinary Definition of the Products of Scientific Creation]. Budapest: Akadémiai Kiadó.

Pedroni, M. - Volonté, P. (2008): La creativitá nelle professioni. Bolzano: Bozen-Bolzano University Press.

Reut, D. (2013): Economics' Double Context. Unpublished manuscript.

Surkova, I. (2012): Towards a Creativity Framework. Society and Economy 34(1):115-138.

Watson, J. D. - Berry, A. (2003): DNA: The secret of life. Knopf.

Wilson, E. O. (2006): The Future of Life. Abacus.

\section{Appendix}

\section{Questionnaire on Creative Techniques}

Gender: $\square$ Male $\quad \square$ Female

Nationality: $\square$ Iranian $\square$ Hungarian $\quad \square$ Latvian Other:

Age:

Position at workplace: $\square$ Professor $\quad \square$ Associate Professor

$\square$ Assistant Professor $\quad \square$ PhD student

Please write about one, two or three major professional tasks that you have already solved. (e.g. I came up with more economical and effective way to cure patients of heart disease, and as a result a lot of patients were cured and left the hospital earlier than it was in their cases expected.) 
$\square$ Yes $\square$ No

2. If you have used Creative Techniques, what Creative Techniques have you used?

$\square$ Synectics (by W.J. Gordon)

$\square$ Brainstorming (by A. Osborn)

$\square$ CPS (by A. Osborn and S. Parnes)

$\square$ Heuristics (by G. Polya and H. Simon)

$\square$ Six Thinking Hats (by E. de Bono)

口TRIZ (by G. S. Altschuller)

Other:

3. Do you use Creative Techniques at work now?

$\square$ Yes $\square$ No

$\underline{4 .}$ Please answer this question if you answered question one "Yes" and question three "Yes", why:

$\square$ Creative Techniques are useful

$\square$ I am obliged to use them

Other:

5. Please answer this question if you answered question one "No" and question three "No", why:

$\square$ Creative Techniques are not useful

$\square$ I am not obliged to use them

$\square$ I am not familiar with Creative Techniques

Other:

6. Please answer this question if you answered question one "No" and question three "Yes", why:

$\square$ I learned them and found them useful

$\square \mathrm{I}$ have to use them now

Other: 
7. Please answer this question if you answered question one "Yes" and question three "No", why:

$\square$ I became disappointed regarding Creative Techniques

$\square$ Creative Techniques are forbidden at my workplace

Other: 